\title{
Sporichthya brevicatena sp. nov.
}

\author{
Tomohiko Tamura, ${ }^{1}$ Masayuki Hayakawa² and Kazunori Hatano'
}

\author{
Author for correspondence: Tomohiko Tamura. Tel: +8163006555 . Fax: +8163006814 . \\ e-mail: k90089@simail.ne.jp
}

\footnotetext{
1 Institute for Fermentation Osaka, 17-85 Jusohonmachi 2-chome, Yodogawa-ku, Osaka 532-8686, Japan

2 Department of Applied Chemistry and Biotechnology, Faculty of Engineering, Yamanashi University, 3-11 Takeda 4chome, Kofu, Yamanashi 400-8510, Japan
}

\begin{abstract}
A strain was isolated from soil that formed short chains of aerial mycelium dividing into motile spores on an agar medium, but not substrate mycelium. The organism had menaquinone $\mathbf{9}\left(\mathrm{H}_{8}\right)$, LL-diaminopimelic acid in the cell wall amino acids and a DNA G+C content of $71 \mathrm{~mol} \%$. On the basis of the morphological and chemotaxonomic characteristics and phylogenetic analysis, this strain was classified into the genus Sporichthya. DNA-DNA hybridization revealed that the strain differed from the known species, Sporichthya polymorpha. Therefore, a new species, Sporichthya brevicatena sp. nov., is proposed. The type strain is S. brevicatena YU720-21' (=IFO 16195').
\end{abstract}

Keywords: suborder Frankineae, Sporichthya brevicatena sp. nov.

\section{INTRODUCTION}

The genus Sporichthya established by Lechevalier et al. (1968) has LL-diaminopimelic acid in its peptidoglycan and forms short spore chains. Although the appearance of Sporichthya clearly distinguishes it from the genus Streptomyces, it is classified among related organisms of the genus Streptomyces in Bergey's Manual of Systematic Bacteriology (Locci, 1989) because its cell wall is of type I. Rainey et al. (1993) revealed that Sporichthya polymorpha represents a novel line of descent within the order Actinomycetales by phylogenetic analysis based on $16 \mathrm{~S}$ rDNA sequences. Stackebrandt et al. (1997) placed the genus Sporichthya in the family Sporichthyaceae of the suborder Frankineae. The families belonged to the suborder Frankineae, which contains the genera Frankia (Lechevalier \& Lechevalier, 1989a), Sporichthya (Lechevalier et al., 1968), Geodermatophilus (Luedemann, 1968), Blastococcus (Ahrens \& Moll, 1970), Acidothermus (Mohagheghi et al., 1986) and Microsphaera (Yoshimi et al., 1996). Recently, Cryptosporangium (Tamura et al., 1998) was proposed as a new genus belonging to the family Sporichthyaceae.

During studies on rare actinomycetes, we isolated a strain from soil, YU720-21 ${ }^{\mathrm{T}}$, which produced short spore chains. The isolate contained LL-diaminopimelic acid in the peptidoglycan. Its morphological and chemotaxonomic characteristics, phylogenetic analy-

\footnotetext{
Abbreviations: ISP, International Streptomyces Project; NJ method, neighbour-joining method.

The GenBank/EMBL/DDBJ accession number for the sequence reported in this paper is AB0006164.
}

sis and DNA-DNA hybridization data indicated that the isolate belonged to the genus Sporichthya but was taxonomically distinct from $S$. polymorpha.

In this paper, we describe the characterization and classification of the isolate and propose a new species of the genus Sporichthya for strain YU720-21 ${ }^{\mathrm{T}}$, Sporichthya brevicatena $\mathrm{sp}$. nov.

\section{METHODS}

Micro-organisms and culture conditions. Strain YU720-21 ${ }^{\mathrm{T}}$ was isolated from soil samples collected in Yamanashi prefecture, Japan, on humic acid/vitamin (HV) agar (Hayakawa \& Nonomura, 1987) by a capillary method (Hayakawa et al., 1992) improved to include vanillin as a chemoattractant. S. polymorpha IFO $12702^{\mathrm{T}}$ was used for comparison with the isolate. To obtain freeze-dried cells for chemotaxonomic analyses, the culture was grown on yeast extract/starch agar (containing $2 \mathrm{~g}$ yeast extract, $10 \mathrm{~g}$ soluble starch and $18 \mathrm{~g}$ agar in $1000 \mathrm{ml}$ distilled water, $\mathrm{pH}$ $7 \cdot 0$ ) at $28^{\circ} \mathrm{C}$ for $5-7 \mathrm{~d}$.

Morphological and physiological characteristics. The culture grown on HV agar and yeast extract/starch agar for 3-14 d at $28^{\circ} \mathrm{C}$ was observed with a light microscope and a scanning electron microscope (model JSM-5400; JEOL). Samples for scanning electron microscopy were prepared by cutting a block from an agar plate containing the strain, fixing the block in osmium tetroxide vapour at room temperature for $4 \mathrm{~h}$, dehydrating cells through freeze-drying and sputtercoating the preparation with palladium under vacuum.

Motility was observed with a light microscope using cells grown on $\mathrm{HV}$ agar for $7-10 \mathrm{~d}$ at $28^{\circ} \mathrm{C}$, then incubated at $28{ }^{\circ} \mathrm{C}$ for $30-60 \mathrm{~min}$ in sterile water.

Cultural characteristics on the media tested were recorded after $5 \mathrm{~d}$ incubation at $28^{\circ} \mathrm{C}$ according to the International 
Streptomyces Project (ISP) (Shirling \& Gottlieb, 1966). Colours are described in common terminology.

ISP medium 9 was used as basal medium for utilization of sugars. Inorganic salts/starch agar (ISP medium 4) was used for determination of starch hydrolysis. Growth temperature was determined on yeast extract/starch agar. Calcium malate medium (calcium malate $1 \%, \mathrm{NH}_{4} \mathrm{Cl} 0.05 \%$, $\mathrm{K}_{2} \mathrm{HPO}_{4} 0.05 \%$, agar $1.8 \%$, pH 7.0 ) was used for determining solubility of calcium malate. ISP medium 8 was used for nitrate determination. Gelatin medium (gelatin $20 \%, \mathrm{pH}$ 7.0 ) and glucose/peptone/gelatin medium (glucose $2 \%$, peptone $0.5 \%$, gelatin $20 \%, \mathrm{pH} 7.0$ ) were used for determination of gelatin liquefaction. Skim milk (10\%; Difco) was used for determination of milk peptonization.

Analyses of chemotaxonomic characteristics. The analyses of whole-cell sugars, cellular fatty acids, isoprenoid quinones and DNA base composition were performed as described previously (Tamura et al., 1994). The isomers of diaminopimelic acid were determined by TLC (Hasegawa et al., 1983).

Preparation of DNA. Total DNA was prepared according to the method of Saito \& Miura (1963) with modifications. Cells were harvested from $5 \mathrm{ml}$ yeast extract/starch agar. After washing three times with $2 \mathrm{ml} 50 \mathrm{mM}$ EDTA (pH 7.5), cells were suspended in $500 \mu \mathrm{l} 5 \mathrm{mM}$ EDTA (pH 8.0). The cell suspension was transferred to a $1.5 \mathrm{ml}$ Eppendorf microtube and $50 \mu \mathrm{l}$ lytic solution $[5 \mathrm{mg}$ achromopeptidase $\mathrm{ml}^{-1}$ and $7.5 \mathrm{mg}$ lysozyme $\mathrm{ml}^{-1}$ (both from Wako Pure Chemical Industries) in $10 \mathrm{mM}$ Tris $/ \mathrm{HCl}, \mathrm{pH} 8.0$ ] was added for spheroplasting and the mixture was incubated for $2 \mathrm{~h}$ at $37^{\circ} \mathrm{C}$. Spheroplasts were lysed gently by adding $50 \mu \mathrm{l}$ $20 \%$ SDS and incubating for $10 \mathrm{~min}$ at $65^{\circ} \mathrm{C}$. Phenol/ chloroform/isoamyl alcohol $(25: 24: 1)$ extraction followed by phenol extraction was carried out and crude DNA was obtained by 2-propanol precipitation. The precipitate was rinsed with $70 \%$ ethanol, dried and dissolved in $0.2 \mathrm{ml} 1 \times$ TE ( $1 \mathrm{mM}$ EDTA, $10 \mathrm{mM}$ Tris/HCl, $\mathrm{pH} 8 \cdot 0)$. After addition of $150 \mu \mathrm{l}$ ice-cold ethanol, the precipitate was harvested by centrifugation (12000 r.p.m., $5 \mathrm{~min}$ ) and resuspended completely in $0.3 \mathrm{ml} 10 \times \mathrm{TE}$. After RNase A and RNase $\mathrm{T}_{1}$ (both from Sigma) and proteinase K (Wako Pure Chemical Industries) treatments, phenol/chloroform/isoamyl alcohol $(25: 24: 1)$ extraction followed by phenol extraction was carried out and DNA was obtained by 2-propanol precipitation. The precipitate was rinsed with $70 \%$ ethanol, dried and dissolved in $50 \mu \mathrm{l}$ distilled water. The concentration of DNA solution was measured by using a photometer (Beckman DU-65). DNA samples having an $A_{260} /$ $A_{280}$ ratio of 1.8-1.9 were used in the DNA similarity experiment.

PCR amplification and sequencing of 16S rDNA. 16S rDNA was amplified by PCR (Saiki et al., 1988) using TaKaRa Taq (Takara Shuzo) and a pair of primers, 5'-GAGTTTGATCCTGGCTCAG-3' [identical to positions 9-27 in the Escherichia coli numbering system (Brosius et al., 1978)] and 5'-AAGGAGGTGATCCAGCC-3' (complementary to positions 1541-1525). The conditions for thermal cycling were denaturation of the target DNA at $96^{\circ} \mathrm{C}$ for $2 \mathrm{~min}$ followed by 30 cycles of denaturation at $95^{\circ} \mathrm{C}$ for $1 \mathrm{~min}$, primer annealing at $55^{\circ} \mathrm{C}$ for $1 \mathrm{~min}$, and primer extension at $72{ }^{\circ} \mathrm{C}$ for $2 \mathrm{~min}$. At the end of cycling, the reaction mixture was held at $72{ }^{\circ} \mathrm{C}$ for $5 \mathrm{~min}$, then cooled to $4{ }^{\circ} \mathrm{C}$.

The $1.5 \mathrm{~kb}$ amplified $16 \mathrm{~S}$ rDNA was subjected to cycle sequencing with a ThermoSequenase fluorescent-labelled primer cycle sequencing kit with 7-deaza-dGTP (Amersham) according to the manufacturer's protocol, with the following primers: 5'-GAGTTTGATCCTGGCTCAG-3' (complementary to positions 9-27); 5'-CTCCTACGGGAGGCAGCAG-3' (complementary to positions 339-357); 5'-GTATTACCGCGGCTGCTG-3' (complementary to positions 536-519); 5'-GGATTAGATACCCTGGTAGTC-3' (complementary to positions 785-805); 5'-CTACCAGGGTATCTAAT-3' (complementary to positions 803-787); 5'-GCAACGAGCGCAACCC-3' (complementary to positions 1099-1114); 5'-AGGGTTGCGCTCGTTG-3' (complementary to positions 1115-1100); 5'-GCGGTGTGTACAAGGCCC-3' (complementary to positions 13821365); and 5'-AAGGAGGTGATCCAGCC-3' (complementary to positions 1541-1525). The conditions for thermal cycling were denaturation of the target DNA at $95^{\circ} \mathrm{C}$ for $5 \mathrm{~min}$ followed by 30 cycles of denaturation at $95^{\circ} \mathrm{C}$ for $0.5 \mathrm{~min}$, primer annealing at $55^{\circ} \mathrm{C}$ for $0.5 \mathrm{~min}$, and primer extension at $72^{\circ} \mathrm{C}$ for $1 \mathrm{~min}$. The products were analysed with a Pharmacia $A L F$ DNA Sequencer II according to the manufacturer's protocol.

Phylogenetic analysis. 16S rDNA sequences of the strain and reference organisms were aligned against that of Streptomyces ambofaciens (Pernodet et al., 1989). The CLusTal W v.1.6 software (Thompson et al., 1994) package was used to generate the evolutionary distances [the $K_{\text {nuc }}$ value of Kimura (1980)] and the similarity values; the phylogenetic tree was constructed by the neighbour-joining (NJ) method (Saitou $\&$ Nei, 1987) from $K_{\text {nuc }}$ values. The topology of the phylogenetic tree was evaluated by the bootstrap resampling method of Felsenstein (1985) with 1000 replicates.

Measurement of DNA similarity. The microplate-hybridization method developed byEzaki et al. $(1988,1989)$ was applied with minor modifications to determine DNA similarity. A heat-denatured sample DNA $(1 \mu \mathrm{g})$ was immobilized in a well of a microplate (Immuno plate II; Nunc) at $28^{\circ} \mathrm{C}$ for $3 \mathrm{~h}$. The microplate was dried at $60^{\circ} \mathrm{C}$ for $3 \mathrm{~h}$. Probe DNA was prepared by labelling with photobiotin acetate (Bresatec) according to the supplier's instructions. Before hybridization with probe DNA, $0.2 \mathrm{ml}$ prehybridization solution $[50 \%$ deionized formamide, $2 \times \operatorname{SSC}(1 \times$ $\mathrm{SSC}$ is $0.15 \mathrm{M} \mathrm{NaCl}, 0.015 \mathrm{M}$ trisodium citrate, $\mathrm{pH} 7.0), 5 \times$ Denhardt's solution $(1 \times$ Denhardt's solution is $0.02 \%$ bovine serum albumin, $0.02 \%$ polyvinylpyrrolidone and $0.02 \%$ Ficoll 400 ) and heat-denatured and sonicated salmon testes DNA $\left.\left(0 \cdot 1 \mathrm{mg} \mathrm{ml}^{-1}\right)\right]$ was added to the well and the plate was incubated for $30 \mathrm{~min}$ at $37^{\circ} \mathrm{C}$. The prehybridization solution was discarded and $0.1 \mathrm{ml}$ hybridization solution $(2.5 \%$ dextran sulfate and $2 \mu \mathrm{g}$ heat-denatured probe DNA ml-1) was added to the well. Hybridization was performed at $55^{\circ} \mathrm{C}$ for $3 \mathrm{~h}$ and then wells were washed four times with $0.3 \mathrm{ml} 1 \times \mathrm{SSC}$. After washing, $0.1 \mathrm{ml}$ PBS ( $8 \mathrm{mM}$ $\mathrm{Na}_{2} \mathrm{HPO}_{4}, 1.5 \mathrm{mM} \mathrm{KH} \mathrm{PO}_{4}, 137 \mathrm{mM} \mathrm{NaCl}, 2.7 \mathrm{mM} \mathrm{KCl}$, $\mathrm{pH} 7.2$ ) containing $0.5 \%$ bovine albumin and $0.1 \%$ streptoavidin- $\beta$-galactosidase conjugate (Boehringer Mannheim) was added to the well and the plate was kept at $37^{\circ} \mathrm{C}$ for $10 \mathrm{~min}$ at room temperature. After incubation at $37^{\circ} \mathrm{C}$ for $10 \mathrm{~min}$, wells were washed four times with $0.3 \mathrm{ml} 1 \times$ SSC. For the $\beta$-galactosidase assay, $0.2 \mathrm{ml} \mathrm{PBS}$ containing $1 \mathrm{mM}$ $\mathrm{MgCl}_{2}$ and $0.1 \mathrm{mg} \mathrm{4-methylumbelliferyl-} \beta$-D-galactopyranoside $\mathrm{ml}^{-1}$ (Wako Pure Chemical Industries) was added and plates were incubated for an appropriate time at $37^{\circ} \mathrm{C}$ and fluorescence intensity was measured in wells with a microplate reader MTP-32 (Corona Electric) every $15 \mathrm{~min}$. DNA similarity was calculated by using the following equation:

DNA similarity $(\%)=100(\mathrm{X}-\mathrm{N}) /(\mathrm{P}-\mathrm{N})$,

where $\mathrm{X}$ is fluorescence intensity of unknown DNA, $\mathrm{P}$ is fluorescence intensity of DNA used in making the probe 
(positive reference) and $\mathrm{N}$ is fluorescence intensity of calf thymus DNA (negative reference).

\section{RESULTS AND DISCUSSION}

\section{Morphological observations}

Strain YU720-21 $1^{\mathrm{T}}$ was observed in 4-5 d cultures on HV agar and yeast extract starch agar (Fig. 1). Substrate mycelium was not observed. The aerial
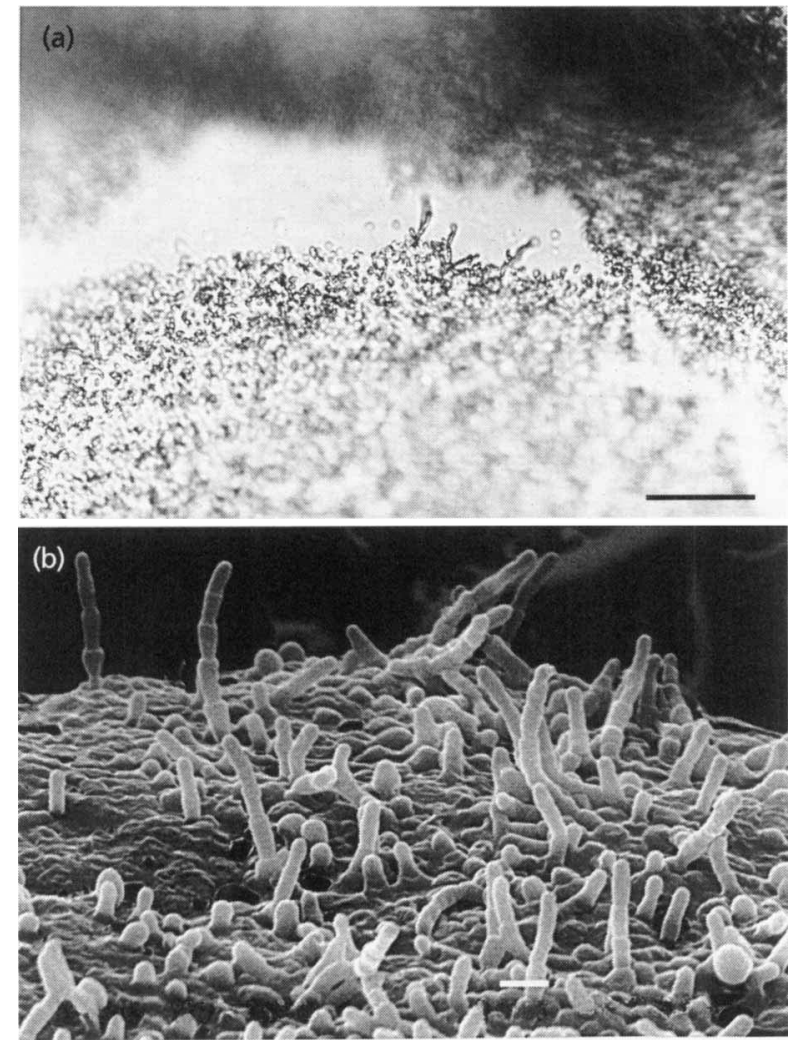

Fig. 1. (a) Light micrograph of isolate $Y U 720-21^{\top}$ grown on $H V$ agar for $5 \mathrm{~d}$ at $28^{\circ} \mathrm{C}$ (bar, $20 \mu \mathrm{m}$ ) and (b) scanning electron micrograph of isolate YU720-21 ${ }^{\top}$ grown on yeast extract/starch agar for $4 \mathrm{~d}$ at $28^{\circ} \mathrm{C}$ (bar, $\left.1 \mu \mathrm{m}\right)$. hyphae were maintained upright on the surface of the medium. Most spore chains were short, but some were long $(15-20 \mu \mathrm{m})$. Ordinary cells were rod-shaped or oval (approximate i.d. $0 \cdot 5-1.5 \mu \mathrm{m}$ ) and many spores showed motility after incubation at $28^{\circ} \mathrm{C}$ for $30 \mathrm{~min}$ in distilled water.

\section{Growth characteristics}

Table 1 shows the growth characteristics of the isolate and $S$. polymorpha IFO $12702^{\mathrm{T}}$. The isolate formed greyish-white colonies on most agar media. It showed good growth on glycerol/asparagine agar (ISP medium 5) and tyrosine agar (ISP medium 7). Traces of moderate brown soluble pigments were observed when the isolate was cultured over 1 week on tyrosine agar (ISP medium 7).

\section{Physiological characteristics}

Table 2 shows the physiological properties of the isolate and $S$. polymorpha IFO $12702^{\mathrm{T}}$. Strain YU720$21^{\mathrm{T}}$ utilized glucose, inositol, raffinose, saccharose, Dxylose, glycerol, lactose, D-galactose and melibiose as a sole carbon source. It was positive for nitrate reduction and negative for peptonization of milk, gelatin liquefaction, hydrolysis of starch and decomposition of calcium malate. It grew at $15-37^{\circ} \mathrm{C}$; good growth occurred at $20-30^{\circ} \mathrm{C}$.

\section{Chemotaxonomic characteristics}

Table 3 shows the menaquinone composition, wholecell sugars and the $\mathrm{G}+\mathrm{C}$ content of the DNA. The major menaquinone of the isolate was $\mathrm{MK}-9\left(\mathrm{H}_{8}\right)$; small amounts of $\mathrm{MK}-8\left(\mathrm{H}_{6}\right)$ and $\mathrm{MK}-9\left(\mathrm{H}_{6}\right)$ were also present. The cell walls of strain YU720-21 $1^{\mathrm{T}}$ contained LL-diaminopimelic acid, indicating wall chemotype I according to Lechevalier \& Lechevalier (1970). The isolate contained large amounts of glucose and small amounts of mannose and galactose in the whole-cell hydrolysates. The $\mathrm{G}+\mathrm{C}$ content of DNA was 71

Table 1. Cultural characteristics of isolate YU720-21 ${ }^{\top}$ and S. polymorpha IFO $12702^{\top}$

\begin{tabular}{|c|c|c|c|c|c|}
\hline \multirow[t]{2}{*}{ Medium } & \multicolumn{3}{|c|}{ YU720-21 ${ }^{\mathrm{T}}$} & \multicolumn{2}{|c|}{ IFO $12702^{\mathrm{T}}$} \\
\hline & Growth & Colour of colony & Soluble pigment & Growth & $\begin{array}{l}\text { Colour of } \\
\text { colony }\end{array}$ \\
\hline $\begin{array}{l}\text { Yeast extract/malt extract agar (ISP } \\
\text { medium 2) }\end{array}$ & Moderate & Greyish-white & & Moderate & Greyish-white \\
\hline Oatmeal agar (ISP medium 3) & Moderate & Yellowish-white & & Poor & Colourless \\
\hline Inorganic salts/starch agar (ISP medium 4) & Moderate & Greyish-white & & Moderate & Greyish-white \\
\hline Glycerol/asparagine agar (ISP medium 5) & Good & Greyish-white & & Good & Greyish-white \\
\hline $\begin{array}{l}\text { Peptone/yeast extract iron agar (ISP } \\
\text { medium 6) }\end{array}$ & Poor & Greyish-white & & Poor & Colourless \\
\hline Tyrosine agar (ISP medium 7) & Good & Greyish-white & Moderate brown & Good & Greyish-white \\
\hline
\end{tabular}


Table 2. Phenotypic characteristics of isolate YU720-21 and S. polymorpha IFO $12702^{\top}$

\begin{tabular}{|c|c|c|}
\hline Characteristic & YU720-21 ${ }^{\mathrm{T}}$ & IFO $12702^{\mathrm{T}}$ \\
\hline \multicolumn{3}{|l|}{ Utilization of :* } \\
\hline D-Glucose & + & + \\
\hline Inositol & + & + \\
\hline Raffinose & + & + \\
\hline Saccharose & + & \pm \\
\hline D-Fructose & - & - \\
\hline D-Mannitol & \pm & - \\
\hline L-Rhamnose & - & + \\
\hline D-Xylose & + & - \\
\hline Glycerol & + & - \\
\hline Lactose & + & + \\
\hline D-Galactose & + & + \\
\hline Maltose & \pm & \pm \\
\hline D-Mannose & \pm & + \\
\hline Melibiose & + & - \\
\hline $\begin{array}{l}\text { Solubility of calcium } \\
\text { malate }{ }^{\dagger}\end{array}$ & - & - \\
\hline Starch hydrolysis $\dagger$ & - & - \\
\hline Nitrite from nitrate $\dagger$ & + & + \\
\hline Peptonization of milk $\uparrow$ & - & - \\
\hline Gelatin liquefaction $\dagger$ & - & - \\
\hline \multicolumn{3}{|l|}{ Pigmentation in $: \uparrow$} \\
\hline ISP-6 & - & - \\
\hline ISP-7 & Weak (brown) & - \\
\hline \multicolumn{3}{|l|}{$\begin{array}{l}\text { Growth temperature } \\
\left({ }^{\circ} \mathrm{C}\right): *\end{array}$} \\
\hline 10 & - & - \\
\hline 15 & \pm & - \\
\hline 20 & ++ & + \\
\hline 25 & ++ & + \\
\hline 30 & ++ & + \\
\hline 37 & \pm & + \\
\hline 45 & - & - \\
\hline
\end{tabular}

*Growth: ++ , good; + , moderate; \pm , poor; - , none.

$\dagger+$, positive; - , negative.

mol \%. Table 4 shows the major cellular fatty acids of the isolate, iso- $\mathrm{C}_{16: 0}, \mathrm{C}_{17: 1}, \mathrm{C}_{17: 0}$ and 10-methyl $\mathrm{C}_{18: 0}$. The fatty acid type of the isolate is $3 a$ according to Kroppenstedt (1985).

\section{DNA-DNA hybridization}

The level of DNA relatedness between strain YU720$21^{\mathrm{T}}$ and $S$. polymorpha IFO $12702^{\mathrm{T}}$ was less than $30 \%$ (20-28\%). The results of DNA-DNA hybridization studies showed that strain YU720-21 $1^{\mathrm{T}}$ is a distinct species from $S$. polymorpha IFO $12702^{\mathrm{T}}$.

\section{Phylogenetic position}

The 16S rDNA sequence of strain YU720-21 ${ }^{\mathrm{T}}$ from positions 28-1524 [Escherichia coli numbering system (Brosius et al., 1978), total 1490 bases] was determined.
Table 3. Chemotaxonomic characteristics of isolate YU720-21 ${ }^{\top}$

\begin{tabular}{|c|c|}
\hline Characteristic & YU720-21 ${ }^{\mathrm{T} *}$ \\
\hline \multicolumn{2}{|c|}{ Menaquinone composition: } \\
\hline $\mathrm{MK}-8\left(\mathrm{H}_{6}\right)$ & $23 \cdot 4$ \\
\hline MK-9( $\left.\mathrm{H}_{6}\right)$ & $13 \cdot 6$ \\
\hline MK-9 $\left(\mathrm{H}_{8}\right)$ & $62 \cdot 9$ \\
\hline \multicolumn{2}{|c|}{ Sugar composition of whole cells: } \\
\hline Glucosamine & $13 \cdot 2$ \\
\hline Ribose & ND \\
\hline Mannose & $6 \cdot 0$ \\
\hline Arabinose & ND \\
\hline Galactose & $16 \cdot 2$ \\
\hline Xylose & ND \\
\hline Glucose & $46 \cdot 8$ \\
\hline $\mathrm{G}+\mathrm{C}$ content of DNA & $71 \cdot 0$ \\
\hline
\end{tabular}

ND, Not detected.

*Values given as percentages except DNA G $+\mathrm{C}$ content which is given in $\mathrm{mol} \%$.

Table 4. Cellular fatty acid compositions of isolate YU720-21 and S. polymorpha

\begin{tabular}{|lcc|}
\hline Fatty acid & YU720-21 $^{\mathbf{T}}$ & S. polymorpha \\
\hline Iso-branched fatty acids & & \\
$\mathrm{C}_{16: 0}$ & $24 \cdot 4$ & $8 \cdot 9$ \\
$\mathrm{C}_{18: 0}$ & Trace & $7 \cdot 5$ \\
Saturated fatty acids & & \\
$\mathrm{C}_{14: 0}$ & & $4 \cdot 5$ \\
$\mathrm{C}_{15: 0}$ & $2 \cdot 8$ & $6 \cdot 1$ \\
$\mathrm{C}_{16: 0}$ & $6 \cdot 6$ & $24 \cdot 4$ \\
$\mathrm{C}_{17: 0}$ & $17 \cdot 1$ & \\
$\mathrm{C}_{18: 0}$ & $1 \cdot 8$ & \\
Unsaturated fatty acids & & \\
$\mathrm{C}_{16: 1}$ & $2 \cdot 5$ & $9 \cdot 9$ \\
$\mathrm{C}_{17: 1}$ & $18 \cdot 5$ & $20 \cdot 9$ \\
$\mathrm{C}_{18: 1}$ & $2 \cdot 5$ & $5 \cdot 3$ \\
10 -methyl fatty acids $_{C_{18: 0}}$ & & \\
$\mathrm{C}_{19: 0}$ & $17 \cdot 5$ & \\
Unidentified fatty acids & $3 \cdot 4$ & \\
\hline
\end{tabular}

* Data from Rainey et al. (1993).

For the reference organisms, the positions at which secondary structures varied between strains and at which sequences were not determined were excluded from the phylogenetic analysis, in which a total of $1112 \mathrm{nt}$ were compared after elimination of these sites. Fig. 2 depicts the phylogenetic tree obtained by applying the NJ method to $K_{\text {nuc }}$ values.

Strain YU720-21 ${ }^{\mathrm{T}}$ formed a monophyletic cluster with $S$. polymorpha. The fidelity of this cluster was supported by bootstrap analysis at a confidence level 


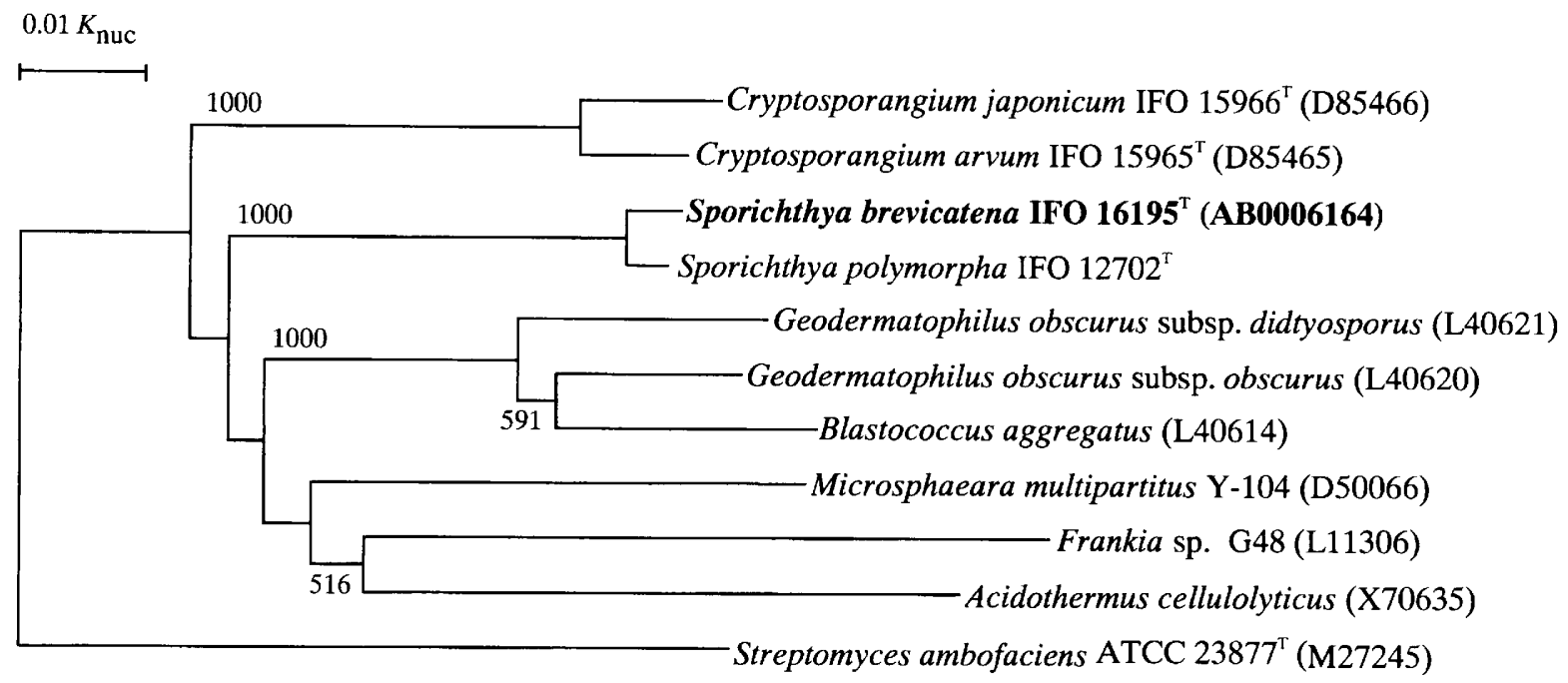

Fig. 2. Phylogenetic tree derived from 165 rDNA sequences of the suborder Frankineae. Streptomyces ambofaciens ATCC $23877^{\top}$ (M27245) was used as the root organism. Bar, $0.01 K_{\text {nuc }}$ in nucleotide sequences. The numbers on the branches are confidence limits estimated from a bootstrap analysis with 1000 replicates (only values above $50 \%$ are indicated).

Table 5. Differential characteristics of Sporichthya species

\begin{tabular}{|c|c|c|}
\hline Characteristic & S. brevicatena & S. polymorpha \\
\hline $\begin{array}{l}\text { Colour of colonies on } \\
\text { ISP-3 }\end{array}$ & Yellowish-white & Colourless \\
\hline \multicolumn{3}{|l|}{ Utilization of:* } \\
\hline D-Mannitol & \pm & - \\
\hline L-Rhamnose & - & + \\
\hline D-Xylose & + & - \\
\hline Glycerol & + & - \\
\hline Melibiose & + & - \\
\hline Major menaquinone & MK-9 $\left(\mathrm{H}_{8}\right)$ & MK $-9\left(\mathrm{H}_{6}\right) \dagger$ \\
\hline Major cellular fatty acid & iso- $\mathrm{C}_{16: 0}$ & $\mathrm{C}_{16: 0}, \mathrm{C}_{17: 1}^{\dagger}$ \\
\hline
\end{tabular}

$*++$, Good; + , moderate; \pm , poor; - , none.

$\dagger$ Data from Rainey et al. (1993).

of $100 \%$. The level of $16 \mathrm{~S}$ rDNA sequence similarity between strain YU720-21 $1^{\mathrm{T}}$ and $S$. polymorpha was $99 \cdot 0 \%$.

The isolate had short aerial mycelium dividing into motile spores on the surface of solid media but no substrate mycelium, LL-diaminopimelic acid in the cell wall, and MK-9( $\left.\mathrm{H}_{8}\right), 9\left(\mathrm{H}_{6}\right), 8\left(\mathrm{H}_{6}\right)$. Morphological features and chemotaxonomic characteristics of the isolate were similar to those of $S$. polymorpha. Furthermore, the phylogenetic tree based on 16S rDNA sequences indicated that the isolate forms a monophyletic cluster with $S$. polymorpha and could be considered as a member of the genus Sporichthya. In the genus Sporichthya, only one species was previously known, S. polymorpha, five strains of which have been isolated worldwide so far (Lechevalier \& Lechevalier, 1989b). The chemotaxonomic characteristics were studied by Rainey et al. (1993). S. polymorpha has MK-9 $\left(\mathrm{H}_{6}\right)$ and MK-9 $\left(\mathrm{H}_{8}\right)$ (in a quantitative ratio of $1 \cdot 5: 1)$ as major isoprenoid quinone and $\mathrm{C}_{16: 0}$ and $\mathrm{C}_{17: 1}$. The isolate has MK-9 $\left(\mathrm{H}_{8}\right), \mathrm{MK}-8\left(\mathrm{H}_{6}\right)$ and MK9( $\left.\mathrm{H}_{6}\right)$ (in a quantitative ratio of $4 \cdot 6: 1 \cdot 7: 1$ ), and iso$\mathrm{C}_{16: 0}, \mathrm{C}_{17: 0}, \mathrm{C}_{17: 1}$ and 10-methyl $\mathrm{C}_{18: 0}$. Therefore, on the basis of physiological and chemotaxonomic characteristics, as well as DNA-DNA hybridization, the isolate was assigned to a new species designated Sporichthya brevicatena sp. nov. This strain has been deposited in the Institute for Fermentation, Osaka as strain IFO $16195^{\mathrm{T}}$. Table 5 summarizes the differential characteristics of the new species and S. polymorpha.

Recently, Suzuki et al. (1997) reported that many Sporichthya species were isolated from samples collected worldwide using gellan gum instead of agar (Suzuki et al., 1997). This suggests that Sporichthya may be commonly distributed. Further study may reveal more diversity in the genus Sporichthya.

\section{Description of Sporichthya brevicatena sp. nov.}

Sporichthya brevicatena (bre.vi.cat.e'na. L. adj. brevis short; L. fem. n. catena chain; M.L. fem. n. brevicatena short chain).

Gram-positive, non-acid-fast and strictly aerobic organism with short spore chains. Substrate mycelia are absent. Spores are oval or short rods (diameter $1 \cdot 3-2.0 \mu \mathrm{m}$ ) and exhibit motility when suspended in sterile distilled water. The organism grows well on ISP 5 and ISP 7. In general, the spore chains are greyishwhite. The temperature range for growth is $15-37^{\circ} \mathrm{C}$; good growth occurs at $20-30{ }^{\circ} \mathrm{C}$. Reduces nitrate to nitrite. Gelatin liquefaction is negative. Does not hydrolyse starch. Does not decompose calcium malate. 
Peptonization of milk is negative. Glucose, inositol, raffinose, saccharose, D-xylose, glycerol, lactose, Dgalactose and melibiose are utilized as a sole carbon source. Cell walls contain LL-diaminopimelic acid. Glucose, galactose and mannose are the characteristic whole-cell sugars. Iso- $\mathrm{C}_{16: 0}, \mathrm{C}_{17: 0}, \mathrm{C}_{17: 1}$ and 10-methyl $\mathrm{C}_{18: 0}$ are the major cellular fatty acids. The DNA $\mathrm{G}+\mathrm{C}$ content of the type strain is $71.0 \mathrm{~mol} \%$. Major menaquinones are MK-9 $\left(\mathrm{H}_{8}\right), \mathrm{MK}-8\left(\mathrm{H}_{6}\right)$ and $\mathrm{MK}$ $9\left(\mathrm{H}_{6}\right)$. Habitat is soil. Type strain is YU720-21 $\left(=\right.$ IFO $\left.16195^{\mathrm{T}}\right)$.

\section{REFERENCES}

Ahrens, R. \& Moll, G. (1970). Ein neues knospendes Bakterium aus der Ostsee. Arch Mikrobiol 70, 243--265.

Brosius, J., Palmer, J. L., Kennedy, J. P. \& Noller, H. F. (1978). Complete nucleotide sequence of a $16 \mathrm{~S}$ ribosomal RNA gene from Escherichia coli. Proc Natl Acad Sci USA 75, 4801-4805.

Ezaki, T., Hashimoto, Y., Takeuchi, T., Yamamoto, H., Liu, S.-L., Matsui, K. \& Yabuuchi, E. (1988). Simple genetic method to identify viridans group streptococci by colorimetric dot hybridization and fluorometric hybridization in microdilution wells. $J$ Clin Microbiol 26, 1708-1713.

Ezaki, T., Hashimoto, Y. \& Yabuuchi, E. (1989). Fluorometric deoxyribonucleic acid-deoxyribonucleic acid hybridization in microdilution wells as an alternative to membrane filter hybridization in which radioisotopes are used to determine genetic relatedness among bacterial strains. Int J Syst Bacteriol 39, 224-229.

Felsenstein, J. (1985). Confidence limits on phylogenies: an approach using the bootstrap. Evolution 39, 783-791

Hasegawa, T., Takizawa, M. \& Tanida, S. (1983). A rapid analysis for chemical grouping of aerobic actinomycetes. J Gen Appl Microbiol 29, 319-322.

Hayakawa, M. \& Nonomura, H. (1987). Humic acid-vitamin agar, a new medium for selective isolation of soil actinomycetes. $J$ Ferment Technol 65, 501-509.

Hayakawa, M., Tamura, T. \& Nonomura, H. (1992). Selective isolation of Actinoplanes and Dactylosporangium from soil by using $\gamma$-collidine as the chemoattractant. $J$ Ferment Bioeng 72, 426-432.

Kimura, M. (1980). A simple method for estimating evolutionary rates of base substitutions through comparative studies of nucleotide sequences. $J$ Mol Evol 16, 111-120.

Kroppenstedt, R. M. (1985). Fatty acid and menaquinone analysis of actinomycetes and related organisms. In Chemical Methods in Bacterial Systematics, pp. 173-199. Edited by M. Goodfellow \& D. E. Minnikin. London: Academic Press.

Lechevalier, M. P. \& Lechevalier, H. A. (1970). Chemical composition as a criterion in the classification of aerobic actinomycetes. Int J Syst Bacteriol 20, 435-443.

Lechevalier, M. P. \& Lechevalier, H. A. (1989a). Genus Frankia Brunchorst 1886, $174^{\mathrm{AL}}$. In Bergey's Manual of Systematic Bacteriology, pp. 2410-2417. Edited by S. T. Williams, M. E. Sharpe \& J. G. Holt. Baltimore: Williams \& Wilkins.

Lechevalier, M. P. \& Lechevalier, H. A. (1989b). Genus Sporichthya Lechevalier, Lechevalier and Holbert 1968, 279 ${ }^{\mathrm{AL}}$. In Bergey's Manual of Systematic Bacteriology, pp. 2507-2508. Edited by S. T. Williams, M. E. Sharpe \& J. G. Holt. Baltimore: Williams \& Wilkins.
Lechevalier, M. P., Lechevalier, H. A. \& Holbert, P. E. (1968). Sporichthya, un nouveau genre de Streptomycetaceae. Ann Inst Pasteur 114, 277-286.

Locci, R. (1989). Section 29. Streptomycetes and related genera. In Bergey's Manual of Systematic Bacteriology, pp. 2451-2508. Edited by P. H. A. Sneath, N. S. Mair, M. E. Sharpe \& J. G. Holt. Baltimore: Williams \& Wilkins.

Luedemann, G. M. (1968). Geodermatophilus, a new genus of the Dermatophilaceae (Actinomycetales). J Bacteriol 96, 1848-1858.

Mohagheghi, A., Grohmann, K., Himmel, M., Leighton, L. \& Updegraff, D. M. (1986). Isolation and characterization of Acidothermus cellulolyticus gen. nov., sp. nov., a new genus of thermophilic, acidophilic, cellulolytic bacteria. Int $J$ Syst Bacteriol 36, 435-443.

Pernodet, J.-L., Borccard, F., Alegre, M.-T., Gargnat, J. \& Guérineau, M. (1989). Organization and nucleotide sequence analysis of ribosomal RNA gene cluster from Streptomyces ambofaciens. Gene 79, 33-46.

Rainey, F. A., Schumann, P., Prauser, H., Toalster, R. \& Stackebrandt, E. (1993). Sporichthya polymorpha represents a novel line of descent within the order Actinomycetales. FEMS Microbiol Lett 109, 263-268.

Saiki, R. K., Gelfand, D. H., Stoffe, S., Scharf, S. J., Higuchi, R., Horn, G. T., Mullis, K. B. \& Erlich, A. (1988). Primer-directed enzymatic amplification of DNA with a thermostable DNA polymerase. Science 239, 487-491.

Saito, H. \& Miura, K. (1963). Preparation of transforming deoxyribonucleic acid by phenol treatment. Biochim Biophys Acta 72, 619-629.

Saitou, N. \& Nei, M. (1987). The neighbor-joining method: a new method for reconstructing phylogenetic trees. Mol Biol Evol 4, 406-425.

Shirling, E. B. \& Gottlieb, D. (1966). Methods for characterization of Streptomyces species. Int J Syst Bacteriol 16, 313-340.

Stackebrandt, E., Rainey, F. A. \& Ward-Rainey, N. L. (1997). Proposal for a new hierarchic classification system, Actinobacteria classis nov. Int J Syst Bacteriol 47, 479-491.

Suzuki, S. i., Okuda, T. \& Komatsubara, S. (1997). Isolation and distribution of Sporichthya in soil. In Abstracts of the 1997 Annual Meeting of the Society for Actinomycetes Japan, abstr. 25, pp. 33. Nagasaki: Society for Actinomycetes Japan.

Tamura, T., Nakagaito, Y., Nishii, T., Hasegawa, T., Stackebrandt, E. \& Yokota, A. (1994). A new genus of the order Actinomycetales, Couchioplanes gen. nov., with descriptions of Couchioplanes caeruleus (Horan and Brodsky 1986) comb. nov, and Couchioplanes caeruleus subsp. azureus subsp. nov. Int J Syst Bacteriol 44, 193-203.

Tamura, T., Hayakawa, M. \& Hatano, K. (1998). A new genus of the order Actinomycetales, Cryptosporangium gen. nov., with descriptions of Cryptosporangium aridum sp. nov. and Cryptosporangium yamanashiensis sp. nov. Int J Syst Bacteriol 48, 995-1005.

Thompson, J. D., Higgins, D. G. \& Gibson, T. J. (1994). CLUSTAL $\mathrm{W}$ : improving the sensitivity of progressive multiple sequence alignment through sequence weighting, positions-specific gap penalties and weight matrix choice. Nucleic Acids Res 22, 4673-4680.

Yoshimi, Y., Hiraishi, A. \& Nakamura, K. (1996). Isolation and characterization of Microsphaera multipartita gen. nov., a polysaccharide-accumulating Gram-positive bacterium from activated sludge. Int J Syst Bacteriol 46, 519-525. 